\title{
Could a Sumatra-like megathrust earthquake occur in the south Ryukyu subduction zone?
}

\author{
Jing-Yi Lin ${ }^{1 *}$, Jean-Claude Sibuet', Shu-Kun Hsu ${ }^{1}$ and Wen-Nan Wu²
}

\begin{abstract}
A comparison of the geological and geophysical environments between the Himalaya-Sumatra and Taiwan-Ryukyu collision-subduction systems revealed close tectonic similarities. Both regions are characterized by strongly oblique convergent processes and dominated by similar tectonic stress regimes. In the two areas, the intersections of the oceanic fracture zones with the subduction systems are characterized by trench-parallel high free-air gravity anomaly features in the fore-arcs and the epicenters of large earthquakes were located at the boundary between the positive and negative gravity anomalies. These event distributions and high-gravity anomalies indicate a strong coupling degree of the intersection area, which was probably induced by a strong resistance of the fracture features during the subduction. Moreover, the seismicity distribution in the Ryukyu area was very similar to the pre-seismic activity pattern of the 2004 Sumatra event. That is, thrust-type earthquakes with a trench-normal $P$-axis occurred frequently along the oceanward side of the mainshock, whereas only a few thrust earthquakes occurred along the continentward side. Therefore, the aseismic area located west of $128^{\circ} \mathrm{E}$ in the western Ryukyu subduction zone could have resulted from the strong plate locking effect beneath the high gravity anomaly zone. By analogy with the tectonic environment of the Sumatra subduction zone, the occurrence of a potential Sumatra-like earthquake in the south Ryukyu arc is highly likely and the rupture will mainly propagate continentward to fulfill the region of low seismicity (approximately $125^{\circ} \mathrm{E}$ to $129^{\circ} \mathrm{E} ; 23^{\circ} \mathrm{N}$ to $26.5^{\circ} \mathrm{N}$ ), which may generate a hazardous tsunami.
\end{abstract}

\section{Background}

The Mw 9.3 Sumatra-Andaman earthquake on December 26, 2004 was the second largest earthquake recorded during the last century. The earthquake triggered a significant uplift of the seafloor and induced a series of devastating tsunamis that attacked the coasts of most landmasses bordering the Indian Ocean. The tsunami run-up was up to $30 \mathrm{~m}$ high and over 230,000 people were killed in 14 countries (Paris et al. 2007). It is one of the deadliest natural disasters and is probably the most extensively analyzed earthquake-tsunami event in history. Since the occurrence of the Sumatra earthquake, the potential for the generation of tsunamis along subduction systems all around the world have been studied and several high risk areas have been identified (Cummins 2007; Gusiakov 2005; Liu et al. 2007).

\footnotetext{
* Correspondence: jylin.gep@gmail.com

${ }^{1}$ Department of Earth Sciences, National Central University, 300 Jhongda Road, Jhongli City, Taoyuan County 32001, Taiwan

Full list of author information is available at the end of the article
}

\section{Methods}

Empirical laws for the possible relation between the occurrences of large subduction zone earthquakes and the related tectonic parameters, such as the convergence rate, slab age, trench sediment thickness, bathymetric features, and plate motion, have been widely investigated (Kanamori, 1979; Pacheco et al., 1993; Peterson and Seno, 1984; Ruff and Kanamori 1983; Stein and Okal 2007; Uyeda and Kanamori 1979). A number of studies found that a faster convergence rate, older plate age, and higher upper plate absolute motion enhanced the triggering of the largest subduction zone events (Peterson and Seno 1984; Ruff and Kanamori 1983; Uyeda and Kanamori 1979), even though the validity of such correlations remains controversial (Pacheco et al. 1993). In less than one decade, several large subduction earthquakes occurred worldwide. Based on a more complex seismicity and subduction parameters catalog, Heuret et al. (2011) suggested that events with $\mathrm{Mw} \geq 8.5$ preferentially occurred in the vicinity of slab edges where the upper plate is continental and the back-arc strain neutral. Consequently, the occurrence of large subduction 
earthquakes seems to favor specific tectonic conditions and the comparison of the geodynamic environments of worldwide subduction zones with those of seismogenic areas where megathrust events occurred may help to identify high-risk potential zones. The Taiwan-Ryukyu margin, which is located at the westernmost corner of the western Philippine Sea plate, may present similarities with the Himalaya-Sumatra zone. In this study, we discuss the geophysical parameters, including plate tectonic framework, tectonic stress pattern, bathymetric characteristics, the spatial distributions of the oceanic fracture zones, and the gravity anomalies of these two subduction systems and suggest that a Sumatra-like earthquake may occur in the south Ryukyu fore-arc area.

\section{Results}

Similar geodynamic contexts for the Sumatra and Ryukyu subduction zones

\section{Plate tectonic framework}

In the Sumatra region, the Indo-Australian plate is subducting northwards beneath the Sunda plate at a rate of approximately $50 \mathrm{~mm} / \mathrm{yr}$ (Briggs et al. 2006; Gahalaut and Gahalaut 2007; Paul et al. 2001), and it is colliding with the Eurasian continent to the west (Curray 2002; Paul et al. 2001). The age of the oceanic plate in the north SumatraAndaman area is about 60 to $80 \mathrm{Ma}$ (Müller et al. 2008). The collision of the India plate with Asia results in the formation of the Himalaya Mountains and in the clockwise bending of the subduction front. From east to west along the Sunda and Andaman trenches, the plate convergence vector becomes oblique (Bock et al. 2003; Michel et al. 2001) (Figure 1a) and the slip is partitioned between the Sumatra trench and the right-lateral Sumatra fault system (Curray 1989; Fitch 1972; Genrich et al. 2000; McCaffrey 1991; McCaffrey et al. 2000; Prawirodirdjo et al. 1997). To the north, the Sumatra fault system is transformed into the spreading center of the Andaman Sea (Curray 1989).

Likewise, the Philippine Sea plate (PHS) subducts beneath the Eurasian plate (EU) along the Suruga-Nankai trough and Ryukyu trench at a rate of 80 to $85 \mathrm{~mm} /$ year in a 300 to $310^{\circ} \mathrm{N}$ direction (Yu et al. 1997) (Figure 1b). The age of the west Philippine basin is roughly 30 to $60 \mathrm{Ma}$ (Hall et al. 1995), which is on the same order as that of the north Sumatra-Andaman area. The Luzon volcanic arc, which belongs to the PHS, collides westward with the EU margin and creates the Taiwan Mountains. Thus, the deformation of the Chinese passive margin by the Luzon arc indenter produced a clockwise bend of the southern Ryukyu arc (Letouzey and Kimura 1985; Sibuet et al. 1987), and the subduction of the PHS, which occurs at an oblique angle of about $40^{\circ} \mathrm{E}$ of Taiwan (Lallemand et al. 1999). Similar to the Sumatra fault system, the median tectonic line (MTL) is a right-lateral shear fault (Kimura 1996), which follows the onland arc volcanoes and is prolonged southwestward by the Okinawa trough back-arc basin.

\section{Tectonic stress pattern}

The stress orientations retrieved from the World Stress Map (WSM) (http://dc-app3-14.gfz-potsdam.de/) (Heidbach et al. 2010) as well as the $P$ - and $T$-axes distribution calculated from focal mechanisms extracted from the Global centroid-moment-tensor (CMT) catalog during the period between 1976 and December 25, 2004 for the Sumatra area and between 1976 and the end of 2011 for the Ryukyu area are shown in Figure 1c,d, respectively. On the basis of the stress regime and epicenter distribution, the focal mechanisms of the Sumatra and Ryukyu subduction zones were further divided into groups in terms of $P$ - and $T$-axes orientations. Groups 1 and 2 represent the thrust and extensional events that occurred along the subduction zone (yellow contour in Figure 1c,d); group 3 illustrates the earthquakes located along the collisional front (yellow dashed contour in Figure 1c,d); and group 4 depicts the events occurring within the oceanic plate (yellow dotted contour in Figure 1c,d). The spatial pattern of the stress regime along the Himalaya-Sumatra collision-subduction zone is in good agreement with that along the Taiwan-Ryukyu collision-subduction zone. Specifically, thrust events with a $P$-axis perpendicular to the trend of the arcs dominate in the subduction areas (group 1 in Figure 1c,d), whereas those with a $P$-axis sub-parallel to the relative plate motion vector occur around the colliding areas (group 3 in Figure $1 \mathrm{c}, \mathrm{d})$. Almost all the extensional earthquakes with a trench-parallel $P$-axis occur in the seaward portion of the collision-subduction system, east of approximately $100^{\circ} \mathrm{E}$ for the Sumatra subduction system and east of approximately $126^{\circ} \mathrm{E}$ for the Ryukyu subduction system (red bars in Figure 1c,d). These extensional events are characterized by a vertical $P$-axis and a scattered $T$-axis distribution probably resulting from changes in the trench geometry (group 2 in Figure 1c,d) (Engdahl et al. 2007; Tanaka et al. 2006). Besides, it is noticeable that for the strike slip and thrust earthquakes occurring in the oceanic domain of the subducting plate, their $T$-axis shows a trench perpendicular direction whereas the $P$-axis is proximately sub-parallel to the relative plate motion (group 4 in Figure 1c,d). Such a stress pattern shows that large portions of the Indo-Australian and PHS are widely affected by the NW-SE compressive deformation due to the collision processes in spite of their large distance from the orogenic belts (Chamot-Rooke et al. 1993; Lin et al. 2013).

\section{Bathymetric characteristics, oceanic fracture zones, and gravity anomalies}

The large-scale features of the oceanic plate observed in the Indo-Australia plate are the Ninety East ridge and 


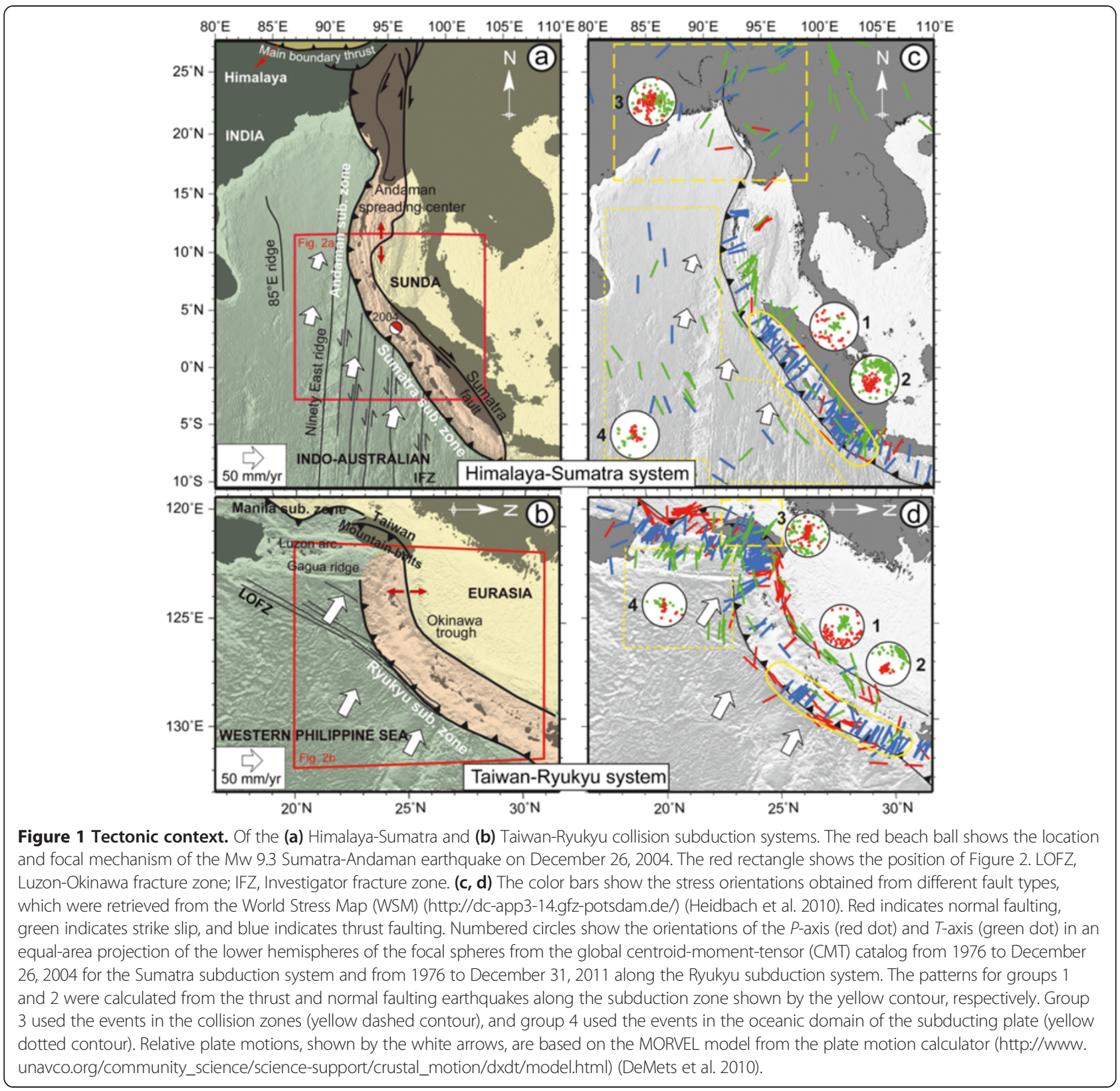

the Investigator Fracture Zone (IFZ) $\left(98^{\circ} \mathrm{E}\right)$ (Larson et al. 1978) (Figure 1a). In between these features, a set of roughly N-S sub-parallel fracture zones were identified from bathymetric, gravity, magnetic, and seismic data (Barckhausen 2006; Delescluse and Chamot-Rooke 2007; Deplus et al. 1998; Lin et al. 2009; Sibuet et al. 2007) (Figures 1a and 2a). Similarly, several major NESW-oriented fracture zones have been defined using bathymetric and magnetic data in the western PHS (e.g. Deschamps and Lallemand 2002; Hsu et al. 2013). Among them, the Luzon-Okinawa fracture zone (LOFZ) is the largest of these features (Figure 1b and 2c) (Hsu et al. 2013). Based on seismic profile interpretations and seismicity distribution, all these fracture zones subduct below the $\mathrm{EU}$, which leads to kinks in the trend of the deformation front (Deplus et al. 1998; Hsu et al. 2013; Kopp and Kukowski 2003; Lange et al. 2010), and this is thought to influence the rupture behavior of major earthquakes (Abercrombie and Ekström 2001; Bilek et al. 2003).

In both subduction systems, the free-air gravity anomaly generally displays positive values for the oceanic plates and portions of fore-arcs (Figure 2b,d). In the Ryukyu subduction zone, the entire fore-arc has a low anomaly value expect in the area where the LOFZ intersects the Ryukyu trench (approximately $125^{\circ} \mathrm{E}$ to $129^{\circ} \mathrm{E}$; $23^{\circ} \mathrm{N}$ to $26.5^{\circ} \mathrm{N}$ ) (Figure 2d). Similarly, in the Sumatra 


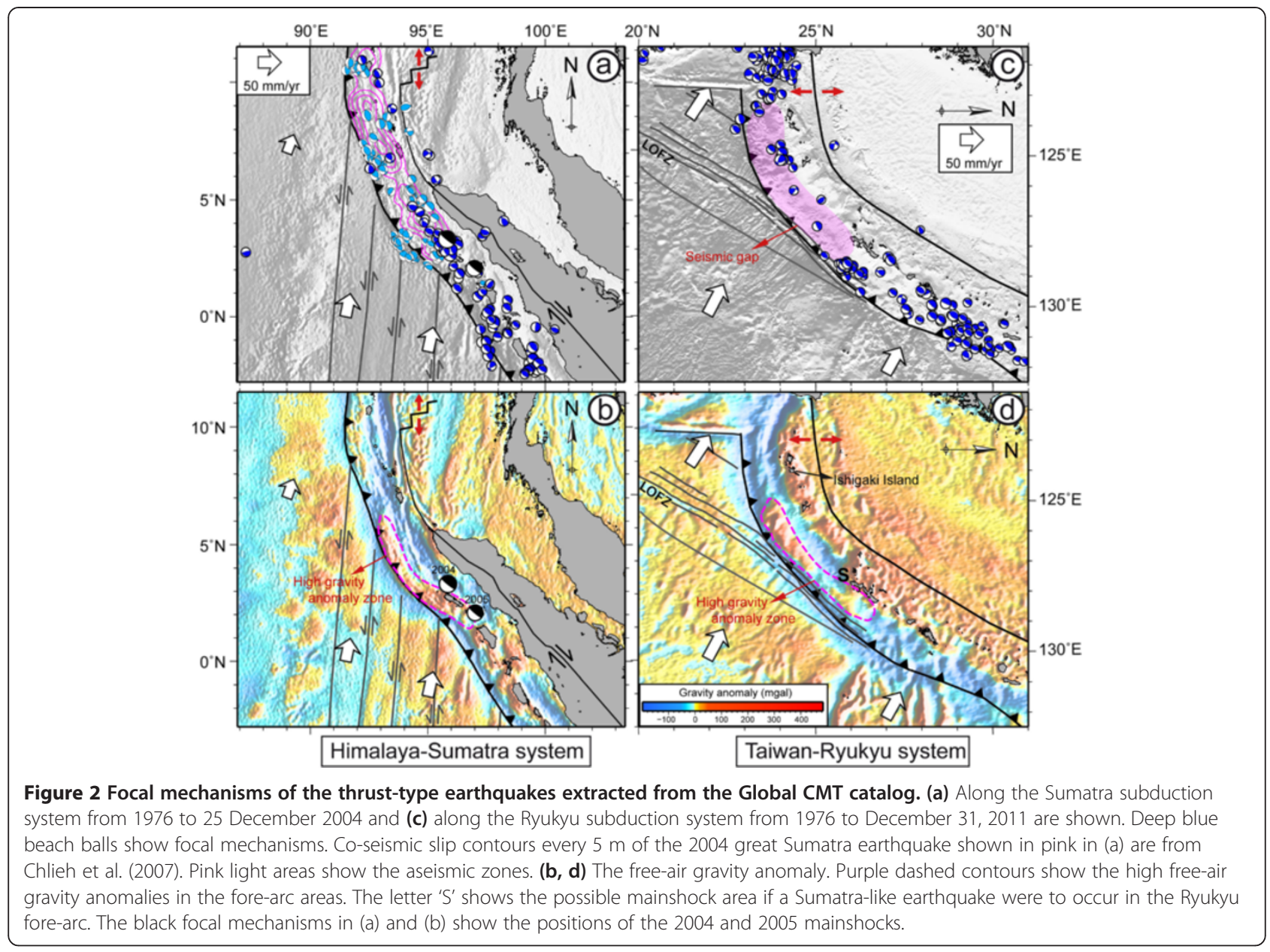

subduction system, a high gravity anomaly zone exists behind the trench (approximately $93^{\circ} \mathrm{E}$ to $97^{\circ} \mathrm{E}$ and $2.5^{\circ} \mathrm{N}$ to $6^{\circ} \mathrm{N}$ ), where series of fracture zones intersect the Sumatra trench (Figure 2b). The size of the two positive free-air gravity anomalies is similar (about $450 \mathrm{~km}$ long).

\section{Discussion}

The role played by the oceanic fracture zones and their orientation

Müller and Landgrebe (2012) have proposed that the fracture zones are characterized by continuous, uplifted ridges, which could be at the origin of strong, persistent coupling at the plate interface. Therefore, the occurrence of large subduction earthquakes (magnitude $>8$ ) is strongly biased towards regions at the intersections of oceanic fracture and subduction zones. This observation is supported by the occurrences of the 2004 Sumatra and 2005 Nias earthquakes, which were both located in areas where the IFZ subridges enter the Sumatra trench (Figure 2a,b). As shown by Figures 1 and 2 and in the previous section, the presence of fracture zones is apparent on both the Indo-Australian and PHS subducting plates. When entering in the subduction system, these fracture zones generally change the trench morphology, which is suggestive of a high resistance of the fracture zone against the subduction (Hsu et al. 2013; Lin et al. 2009). In addition, a trench-parallel high gravity anomaly zones are located at the intersection of the oceanic fracture ridges and the subduction zone, on the landward side of the trench wall for both subduction systems. These gravity anomaly high patterns could be the result of the presence of oceanic fracture zone material stuck beneath the accretionary wedge area (Hsu et al. 2013; Lin et al. 2009), which also suggests that the high resistance of fracture zones could cause a strong coupling environment (Hsu 2001) and block the subduction system. It is worthnoting that epicenters of the 2004 Sumatra and 2005 Nias earthquakes were located on the eastern border of the trench-parallel high anomaly zone at the boundary between the positive and negative gravity anomalies (Figure 2b). Consequently, if this epicenter location of the Sumatra earthquakes is transferred to the Ryukyu subduction system, a possible location for a Sumatra-like earthquake in the Ryukyu area would be in area $S$ (Figure 2d), at the junction of positive and negative gravity anomalies along the boundary of the 
trench-parallel high anomaly. In addition, the size of the positive free-air gravity anomaly in the both areas is similar (about $450 \mathrm{~km}$ long). We therefore infer that the magnitude of a potential earthquake occurring in the Ryukyu fore-arc area could be as large as the 2004 Sumatra earthquake under the premise that the whole potential source area would rupture simultaneously.

Otherwise, the angle between fracture zone directions and the plate motion are different for the two subduction zones and amount to about $120^{\circ}$ and $0^{\circ}$ for the Ryukyu and Sunda subduction zones, respectively (Figures 1 and 2). Based on the distribution of the principle stress axes, the occurrence of earthquakes seems to be mostly controlled by the regional stress regime, i.e., the relative plate motion and the slab-pull mechanism that are caused by the plate collision and subduction processes (Chamot-Rooke et al. 1993; Lin et al. 2013; Yue et al. 2012). It means that even the presence of fracture zones in a subduction system could result in slab coupling in the fore-arc area; their orientation seems to have a relatively small influence on the tectonic stress regime, which greatly affects the seismogenic characteristics of a subduction system. In addition, Müller and Landgrebe (2012) show that the dimension of topographic highs of the oceanic subducting plate is the main factor controlling the megathrust seismogenic potential of a subduction system. What this means is that the fracture zones characterized by laterally continuous ridges and high degrees of structural integrity could cause a strong coupling effect; small volcanic chains present a relatively fragile internal structure, which results in a weak coupling. However, the impact induced by the fracture zone orientation appears to have been neglected. Therefore, we suggest that the difference of fracture zone directions with respect to the two subduction systems may not influence the subduction processes as well as change the seismogenic characteristics.

\section{Pre-seismic distribution of earthquakes}

In Figure 2a,b, the distribution of earthquakes along the Sumatra and Ryukyu subduction is extracted from the Global CMT catalog. Before the 2004 Sumatra earthquake, the thrust earthquakes with a trench-normal $P$-axis extended over the fore-arc area to the southeast of the 2004 mainshock source area (deep blue beach balls in Figure 2a). In contrast, only a few earthquakes were observed in the fore-arc region to the north, which implies that the slab interface north of the mainshock area has been locked and seismic strain has accumulated (Engdahl et al. 2007). During the occurrence of the 2004 mainshock, the accumulated seismic strain was released and the rupture propagated northward (pink contours in Figure 2a) (Chlieh et al. 2007) inducing a huge number of thrust-type events along the trench.
Along the Ryukyu subduction zone, thrust events with a trench-normal $P$-axis are numerous in the vicinity of the trench and fore-arc region, east of the high free-air gravity anomalies (approximately east of $128^{\circ} \mathrm{E}$ ) (Figure 2c,d). However, the seismicity disappears west of this boundary. This spatial distribution of seismic activity is in accord with the pre-seismic pattern of the 2004 Sumatra earthquake (Figure 2a): the thrust earthquakes with a trench-normal $P$-axis occurred frequently on the oceanward side of the mainshock area, whereas few thrust-type earthquakes occurred in the cotinentward side. The area located west of $128^{\circ} \mathrm{E}$ with a low seismicity distribution could be locked between the interface of the PHS and EU along the high free-air gravity anomaly zone and may correspond to a potential rupture area (pink light area in Figure 2c). Therefore, if a Sumatra-like earthquake occurs in the vicinity of $128^{\circ} \mathrm{E}$ (area S), as was mentioned in the previous section, we would expect to see a westward rupture propagation (pink light area in Figure 2c) and the occurrence of thrust-type earthquakes along the present-day aseismic zone in the area west of $128^{\circ} \mathrm{E}$.

\section{Tsunamogenic potential}

In April 1771, a subduction earthquake generated a very large tsunami that struck the south Ryukyu Islands and killed approximately 12,000 people (Ando et al. 2009; Matsumoto et al. 2009; Nakamura 2006, 2009). Reef boulders of building size were transported by the tsunami to beaches along the east and southeast coasts of Ishigaki Island (Goto et al. 2010), which suggests that the source of the tsunami was located east and southeast of Ishigaki Island (Figure 2d). As discussed in the previous section, if a Sumatra-like earthquake occurs along the Ryukyu subduction zone in the vicinity of $128^{\circ} \mathrm{E}$ (area S), there will be a westward propagation of the rupture. This westward rupture movement could be a possible tsunami source similar to the 2004 Sumatra earthquake. Moreover, based on seismic profile interpretations, Hsu et al. (2013) demonstrated the presence of a splay fault system within the trench-parallel high gravity anomaly area of the Ryukyu subduction zone, where a highly resistant subduction due to the integration of significantly developed fracture zones or strong plate coupling is expected (Ando et al. 2009). Similar splay faults have been reported along the Sumatra subduction zone (Sibuet et al. 2007). They branch at the plate interface, present steep dipping angles near the seafloor, and may have generated the devastating tsunamis. As a result, if a Sumatra-like earthquake occurs in the south Ryukyu fore-arc area, this may also trigger a tsunami similar to that during the 2004 Sumatra earthquake and induce serious damage. 


\section{Large historical interplate earthquakes along the subduction system}

Although the tectonic similarity between the Sumatra and Ryukyu subduction systems was denoted, these regions have differences as regards to the occurrence of large historical interplate earthquakes, according to previous studies. Magnitude 8 to 9 class interplate earthquakes occurred frequently in the region of the Sumatra trench, such as the 1797 earthquake ( $\mathrm{Mw} 8.7$ to 8.9), the 1833 earthquake ( $\mathrm{Mw} 8.8$ to 9.2), and the 1861 earthquake (Mw 8.5). In contrast, the risk of great earthquakes and tsunamis was assumed to be low in the Ryukyu trench because the interplate coupling appeared to be weak and great interplate earthquakes ( $\mathrm{Mw}>8.0$ ) had not been recorded historically for about 300 years. However, Nakamura (2013) revealed that the 1771 Yaeyama earthquake (Mw 8.5 from the tsunami height distribution) in the south Ryukyu subduction zone and the 1911 Kikaijima earthquake (Mw 8.0) in the northcentral Ryukyu subduction zone were interplate earthquakes. In addition, two historical tsunamis occurred in 1768 and 1791 on Okinawa Island, and it has been suggested that these were induced by two Mw 8 interplate earthquakes that occurred around the Ryukyu trench on the basis of the source fault model for these two tsunami events (Nakamura 2013). Consequently, the lack of large historic earthquakes along the Ryukyu subduction zone may be due to incomplete records in old documents. Meanwhile, a much higher concentration of oceanic fracture zones can be observed in the Indo-Australian plate than in the PHS. As the subduction of fracture zones can cause larger earthquakes (Müller and Landgrebe 2012), this suggests that there may be a higher possibility for the occurrence of large earthquakes along the Sumatra subduction area.

\section{Comparison with other studies}

The tectonic similarity between the Sumatra and Ryukyu subduction systems has been already raised by $\mathrm{Hsu}$ and Sibuet (2005), and they suggested that there was a potential megathrust earthquake in the Nankai area. Based on more detailed analyses, we found a closer tectonic similarity between the southwestern Ryukyu and Sumatra subduction zoned: the area $S$ in Figure $2 d$ appears to be a possible location for a Sumatra-like earthquake along the Ryukyu subduction zone. Based on a geodetic analysis, Hsu et al. (2012) suggested that the plate interface of the southernmost Ryukyu subduction zone is fully locked and a potential large earthquake (Mw 7.5 to 8.7) and tsunami might occur in the region. However, if the most southwestern end of the Ryukyu subduction zone was totally locked, the overriding EU plate should be closely contacted with the subducting PHS and largely affected by a compressional stress regime.
With this hypothesis, it is difficult to explain the continued opening of the Okinawa trough and the southern migration of the Ryukyu arc already evidenced by geological, geodetic, and seismic data (Sibuet and Hsu 1997; Sibuet et al. 2007). Therefore, we propose that the strong coupling area is located at the intersection of the oceanic fracture ridges and the subduction zone, which block the western movement of the subducting plate resulting in low seismic activity in the southernmost Ryukyu subduction zone (approximately $125^{\circ} \mathrm{E}$ to $129^{\circ} \mathrm{E} ; 23^{\circ} \mathrm{N}$ to $26.5^{\circ} \mathrm{N}$ ).

\section{Conclusions}

In this study, we evaluated the seismic risk along the Ryukyu subduction zone by examining the similarity in tectonic environments between the Himalaya-Sumatra and Taiwan-Ryukyu collision-subduction systems. We found that both of the two systems share the four following common geodynamic contexts. (1) The Indo-Australian plate is subducting beneath the Sunda plate and the Indian portion of the plate collides with the Eurasian continent resulting in the formation of the Himalaya Mountains. Similarly, the Philippine Sea plate subducts beneath the EU and the Luzon volcanic arc creating the Taiwan orogen. (2) Owing to the collisional process, the subduction fronts started to bend clockwise resulting in an oblique subduction and associated partitioning. (3) Oceanic fracture zones with high topographic features exist on both subducting oceanic plates. The intersections of such fracture zones with the subduction systems are associated with trenchparallel gravity highs where the foci of large earthquakes, such as the 2004 Sumatra and the 2005 Nias earthquakes, are located. The locations of these mainshocks may be related to the strong plate coupling resulting from the high resistance of the fracture zones. (4) The spatial distribution of the earthquakes along the Ryukyu arc-trench system is very similar to the pre-seismic activity pattern of the 2004 Sumatra earthquake: the thrust earthquakes with a trenchnormal $P$-axis occur frequently in the oceanward side of the mainshock area, whereas few thrust-type earthquakes occur in the continentward side.

From the similarities in geodynamic contexts between the Sumatra and Ryukyu subduction zones, we suggest that a potential Sumatra-like earthquake may occur along the border of the high gravity anomaly zone located in the fore-arc area of the Ryukyu subduction zone and the present low seismicity area in its western part should correspond to the possible co-seismic rupture area. Such a potential earthquake could generate a risky tsunami that would threaten many countries in Eastern Asia.

Competing interests

The authors declare that they have no competing interests. 


\section{Authors' contributions}

All authors have been involved in drafting the manuscript or revising it critically for important intellectual content. JYL has made substantial contributions to conception of data. All authors read and approved the final manuscript.

\section{Acknowledgements}

We thank two anonymous reviewers for their careful reviews which help a lot to improve this manuscript. Figures were prepared with the Generic Mapping Tool (GMT) software (Wessel and Smith 1998). This research was supported by the Taiwan Earthquake Research Center (TEC) and funded through Ministry of Science and Technology (MOST) with grant numbers MOST-103-3113-M-008-001 and NSC-102-2116-M-008-024. The TEC contribution number for this article is 00104

\section{Author details}

${ }^{1}$ Department of Earth Sciences, National Central University, 300 Jhongda Road, Jhongli City, Taoyuan County 32001, Taiwan. ${ }^{2}$ Institute of Earth Sciences, Academia Sinica, 128, Sec. 2, Academia Road, Nankang, Taipei 11529, Taiwan

\section{Received: 19 November 2013 Accepted: 26 May 2014}

Published: 9 June 2014

\section{References}

Abercrombie RE, Ekström G (2001) Earthquake slip on oceanic transform faults. Nature 410:74-77

Ando M, Nakamura M, Matsumoto T, Furukawa M, Tadokoro K, Furumoto M (2009) Is the Ryukyu subduction zone in Japan coupled or decoupled? - the necessity of seafloor crustal deformation observation. Earth Planets Space 61:1031-1039

Barckhausen U (2006) The segmentation of the subduction zone offshore Sumatra: relations between upper and lower plate. Eos Trans Amer Geophys Union 87:U53A-U0029A, Fall Meet. Suppl., Abstract

Bilek SL, Schwartz SY, DeShon HR (2003) Control of seafloor roughness on earthquake rupture behavior. Geology 31:455-458

Bock Y, Prawirodirdjo L, Genrich JF, Stevens CW, McCaffrey R, Subarya C, Puntodewo SSO, Calais E (2003) Crustal motion in Indonesia from global positioning system measurements. J Geophys Res 108:2367, doi:10.1029/ 2001JB000324

Briggs RW, Sieh K, Meltzner AJ, Natawidjaja D, Galetzka J, Suwargadi B, Hsu YJ, Simons M, Hananto N, Suprihanto I, Prayudi D, Avouac JP, Prawirodirdjo L, Bock Y (2006) Deformation and slip along the Sunda Megathrust in the great 2005 Nias-Simeulue earthquake. Science 311:1897-1901

Chamot-Rooke N, Jestin F, De Voogd B (1993) Intraplate shortening in the central Indian ocean determined from a 2100-km-long north-south deep seismic reflection profile. Geology 21:1043-1046

Chlieh M, Avouac JP, Hjorleifsdottir V, Song TRA, Ji C, Sieh K, Sladen A, Hebert H Prawirodirdjo L, Bock Y, Galetzka J (2007) Coseismic slip and afterslip of the great Mw 9.15 Sumatra-Andaman earthquake of 2004. Bull Seismol Soc Am 97:S152-S173

Cummins PR (2007) The potential for giant tsunamigenic earthquakes in the northern Bay of Bengal. Nature 449:75-78

Curray JR (1989) The Sunda Arc: a model for oblique plate convergence. Neth J Sea Res 24:131-140

Curray JR (2002) Tectonics and history of the Andaman Sea region. Conference on Continent-Ocean Interactions within the East Asian Marginal Seas. abstract, Chapman

Delescluse M, Chamot-Rooke N (2007) Instantaneous deformation and kinematics of the India-Australia Plate. Geophys J Int 168:818-842

DeMets C, Gordon RG, Argus DF (2010) Geologically current plate motions. Geophys J Int 181:1-80

Deplus C, Diament M, Hébert H, Bertrand G, Dominguez S, Dubois J, Malod J, Patriat P, Pontoise B, Sibilla J-J (1998) Direct evidence of active deformation in the eastern Indian oceanic plate. Geology 26:131-134

Deschamps A, Lallemand S (2002) The West Philippine Basin: an Eocene to early Oligocene back arc basin opened between two opposed subduction zones. J Geophys Res 107:EPM 1-1-EPM 1-24

Engdahl ER, Villaseñor A, DeShon HR, Thurber CH (2007) Teleseismic relocation and assessment of seismicity (1918-2005) in the region of the $2004 \mathrm{Mw} 9.0$ Sumatra-Andaman and 2005 Mw 8.6 Nias Island great earthquakes. Bul Seismol Soc Am 97:S43-S61
Fitch T (1972) Plate convergence, transcurrent faults, and internal deformation adjacent to Southeast Asia and the western Pacific. J Geophys Res 77:4432-4460

Gahalaut VK, Gahalaut K (2007) Burma plate motion. J Geophys Res 112, B10402, doi:10.1029/2007JB004928

Genrich J, Bock Y, McCaffrey R, Prawirodirdjo L, Stevens C, Puntodewo S, Subarya C, Wdowinski S (2000) Distribution of slip at the northern Sumatran fault system. J Geophys Res 105(28):327-28,341

Goto K, Kawana T, Imamura F (2010) Historical and geological evidence of boulders deposited by tsunamis, southern Ryukyu Islands, Japan. Earth Sci Rev 102:77-99

Gusiakov V (2005) Tsunami generation potential of different tsunamigenic regions in the Pacific. Mar Geol 215:3-9

Hall R, Ali JR, Anderson CD (1995) Cenozoic motion of the Philippine Sea plate: palaeomagnetic evidence from eastern Indonesia. Tectonics 14:1117-1132

Heidbach O, Tingay M, Barth A, Reinecker J, Kurfeß D, Müller B (2010) Global crustal stress pattern based on the World Stress Map database release 2008 Tectonophysics 482:3-15

Heuret A, Lallemand S, Funiciello F, Piromallo C, Faccenna C (2011) Physical characteristics of subduction interface type seismogenic zones revisited. Geochem Geophys Geosyst 12, Q01004, doi:10.1029/2010GC003230

Hsu S-K (2001) Lithospheric structure, buoyancy and coupling across the southernmost Ryukyu subduction zone: an example of decreasing plate coupling. Earth Planet Sci Lett 186:471-478

Hsu S-K, Sibuet J-C (2005) Earthquake off Japan could generate strong tsunami arrays. Eos, Trans Amer Geophys Union 86:169-170

Hsu YJ, Ando M, Yu SB, Simons M (2012) The potential for a great earthquake along the southernmost Ryukyu subduction zone. Geophys Res Lett 39, L14302

Hsu S-K, Yeh Y-C, Sibuet J-C, Doo W-B, Tsai C-H (2013) A mega-splay fault system and tsunami hazard in the southern Ryukyu subduction zone. Earth Planet Sci Lett 362:99-107

Kanamori H (1979) A semi-empirical approach to prediction of long-period ground motions from great earthquakes. Bull Seismol Soc Am 69:1645-1670

Kimura M (1996) Active rift system in the Okinawa Trough and its northeastern continuation. Bull Disas Prev Res Inst 45:27-38

Kopp H, Kukowski N (2003) Backstop geometry and accretionary mechanics of the Sunda margin. Tectonics 22:1072

Lallemand S, Liu C-S, Dominguez S, Schnürle P, Malavieille J (1999) Trenchparallel stretching and folding of forearc basins and lateral migration of the accretionary wedge in the southern Ryukyus: a case of strain partition caused by oblique convergence. Tectonics 18:231-247

Lange D, Tilmann F, Rietbrock A, Collings R, Natawidjaja DH, Suwargadi BW, Barton P, Henstock T, Ryberg T (2010) The fine structure of the subducted investigator fracture zone in western Sumatra as seen by local seismicity. Earth Planet Sci Lett 298:47-56

Larson RL, Carpenter GB, Diebold JB (1978) A geophysical study of the Wharton Basin near the Investigator fracture zone. J Geophys Res 83:773-782

Letouzey J, Kimura M (1985) Okinawa Trough genesis: structure and evolution of a backarc basin developed in a continent. Mar Petrol Geol 2:111-130

Lin J-Y, Le Pichon X, Rangin C, Sibuet J-C, Maury T (2009) Spatial aftershock distribution of the 26 December 2004 great Sumatra-Andaman earthquake in the northern Sumatra area. Geochem Geophys Geosyst 10, Q05006, doi:10.1029/2009GC002454

Lin J-Y, Chen Y-F, Lee C-S, Hsu S-K, Liang C-W, Lin Y-C, Hsieh H-S (2013) Strike-slip intraplate earthquakes in the Western Philippine Sea Plate. Tectonophysics 608:499-504

Liu N, Chen QF, Niu FL, Chen Y (2007) Rupture of the 2004 Sumatra-Andaman earthquake inferred from direct P-wave imaging. Chin Sci Bull 52:1986-1991

Matsumoto T, Shinjo R, Nakamura M, Doi A, Kimura M, Ono T, Kubo A (2009) Did the submarine, across-arc normal fault system in the southwest RyuKyu arc trigger the 1771 Tsunami? Field evidence from multibeam survey and in-situ observation. J Environ Stud 18:123-129

McCaffrey R (1991) Slip vectors and stretching of the Sumatran forearc. Geology 19:881-884

McCaffrey R, Zwick PC, Bock Y, Prawirodirdjo L, Genrich JF, Stevens CW, Puntodewo S, Subarya C (2000) Strain partitioning during oblique plate convergence in northern Sumatra: geodetic and seismologic constraints and numerical modeling. J Geophys Res 105(28):363-28,376

Michel GW, Yu YQ, Zhu SY, Reigber C, Becker M, Reinhart E, Simons W, Ambrosius B, Vigny C, Chamot-Rooke N, Le Pichon X, Morgan P, Matheussen S (2001) Crustal motion and block behaviour in SE-Asia from GPS measurements. Earth Planet Sci Lett 187:239-244 
Müller RD, Landgrebe T (2012) The link between great earthquakes and the subduction of oceanic fracture zones. Solid Earth Discuss 4:1229-1280

Müller RD, Sdrolias M, Gaina C, Roest WR (2008) Age, spreading rates, and spreading asymmetry of the world's ocean crust. Geochem Geophys Geosyst 9, doi:10.1029/2007GC001743

Nakamura M (2006) Source fault model of the 1771 Yaeyama tsunami, southern Ryukyu Islands, Japan, inferred from numerical simulation. Pure Appl Geophys 163:41-54

Nakamura M (2009) Fault model of the 1771 Yaeyama earthquake along the Ryukyu Trench estimated from the devastating tsunami. Geophys Res Lett 36, L19307

Nakamura M (2013) The 1768 and 1791 Okinawa tsunamis in the Ryukyu Trench region. Eos Trans Amer Geophys Union 87:2574, Fall Meet, Abstract

Pacheco JF, Sykes LR, Scholz CH (1993) Nature of seismic coupling along simple plate boundaries of the subduction type. J Geophys Res 98(14):133-14,159

Paris R, Lavigne F, Wassmer P, Sartohadi J (2007) Coastal sedimentation associated with the December 26, 2004 tsunami in Lhok Nga, west Banda Aceh (Sumatra, Indonesia). Mar Geol 238:93-106

Paul J, Bürgmann R, Gaur VK, Bilham R, Larson KM, Ananda MB, Jade S, Mukal M, Anupama TS, Satyal G, Kumar D (2001) The motion and active deformation of India. Geophys Res Lett 28:647-650

Peterson ET, Seno T (1984) Factors affecting seismic moment release rates. J Geophys Res 89(10):233-10,248

Prawirodirdjo L, Bocl Y, McCaffrey R, Genrich J, Calais E, Stevens C, Puntodewo S, Subarya C, Rais J, Zwick P (1997) Geodetic observations of interseismic strain segmentation at the Sumatra subduction zone. Geophys Res Lett 24:2601-2604

Ruff L, Kanamori H (1983) Seismic coupling and uncoupling at subduction zones. Tectonophysics 99:99-117

Sibuet J-C, Hsu S-K (1997) Geodynamics of the Taiwan arc-arc collision. Tectonophysics 274:221-251

Sibuet J-C, Letouzey J, Barbier F, Charvet J, Foucher JP, Hilde TW, Kimura M, Chiao LY, Marsset B, Muller C (1987) Back arc extension in the Okinawa Trough. J Geophys Res 92(14):041-14,063

Sibuet J-C, Rangin C, Le Pichon X, Singh S, Cattaneo A, Graindorge D, Klingelhoefer F, Lin J-Y, Malod J, Maury T, Schneider J-L, Sultan N, Umber M, Yamaguchi H, Team SA (2007) 26th December 2004 great Sumatra-Andaman earthquake: Co-seismic and post-seismic motions in northern Sumatra. Earth Planet Sci Lett 263:88-103

Stein S, Okal EA (2007) Ultralong period seismic study of the December 2004 Indian Ocean earthquake and implications for regional tectonics and the subduction process. Bull Seismol Soc Am 97:S279-S295

Tanaka Y, Okuno J, Okubo S (2006) A new method for the computation of global viscoelastic post-seismic deformation in a realistic earth model (I)-vertical displacement and gravity variation. Geophys J Int 164:273-289

Uyeda S, Kanamori H (1979) Back-arc opening and the mode of subduction. J Geophys Res 84:1049-1061

Wessel P, Smith WHF (1998) New, improved version of generic mapping tools released. Eos Trans Amer Geophys Union 79:579, doi:10.1029/98EO00426

Yu S-B, Chen H-Y, Kuo L-C (1997) Velocity field of GPS stations in the Taiwan area. Tectonophysics 274:41-59

Yue H, Lay T, Koper KD (2012) En echelon and orthogonal fault ruptures of the 11 April 2012 great intraplate earthquakes. Nature 490:245-249

\section{doi:10.1186/1880-5981-66-49}

Cite this article as: Lin et al:: Could a Sumatra-like megathrust earthquake occur in the south Ryukyu subduction zone? Earth, Planets and Space 2014 66:49.

\section{Submit your manuscript to a SpringerOpen ${ }^{\circ}$ journal and benefit from:}

- Convenient online submission

- Rigorous peer review

- Immediate publication on acceptance

- Open access: articles freely available online

- High visibility within the field

- Retaining the copyright to your article

Submit your next manuscript at $\gg$ springeropen.com 